\title{
Millisia brevis gen. nov., sp. nov., an actinomycete isolated from activated sludge foam
}

Correspondence

Michael Goodfellow

m.goodfellow@ncl.ac.uk
The taxonomy of mycolic-acid-containing actinomycetes has been clarified and extended by the application of genotypic and phenotypic procedures to representatives of established and novel taxa (Goodfellow et al., 1998a, 1999; Gürtler et al., 2004). Actinomycetes characterized by the presence of mycolic acids are classified in the suborder Corynebacterineae Stackebrandt et al. 1997, which encompasses the genera Corynebacterium, Dietzia, Gordonia, Mycobacterium, Nocardia, Rhodococcus, Segniliparus, Skermania, Tsukamurella and Williamsia (Butler et al., 2005; Goodfellow \& Maldonado, 2006). Members of these taxa can be distinguished from one another using a combination of chemotaxonomic and morphological properties, and form distinct lineages in the Corynebacterineae 16S rRNA gene tree. Activated sludge wastewater-treatment plants with foaming problems (Soddell, 1999) are a rich source of mycolic-acid-containing actinomycetes (Lemmer \& Kroppenstedt, 1984; Soddell \& Seviour, 1990, 1995, 1998; Goodfellow et al., 1998b; Stainsby et al., 2002), as exemplified

The GenBank/EMBL/DDBJ accession number for the $16 \mathrm{~S}$ rRNA gene sequences of Millisia brevis strains $\mathrm{J} 81^{\top}$ and $\mathrm{J} 82$ are AY534742 and AY534743, respectively. by Gordonia amarae (Lechevalier \& Lechevalier, 1974) Klatte et al. 1994, Skermania piniformis Chun et al. 1997, Tsukamurella pseudospumae Nam et al. 2004 and Tsukamurella spumae Nam et al. 2003.

Two actinomycetes that showed rudimentary right-angled branching and which produced salmon-pink filamentous colonies were isolated from activated sludge foam by using a micromanipulator (Soddell \& Seviour, 1994). Subsequent studies based on numerical taxonomic and preliminary $16 \mathrm{~S}$ rRNA gene sequence data indicated that the two strains, isolates $\mathrm{J} 81^{\mathrm{T}}$ and J82, might represent a novel genus in the suborder Corynebacterineae (Soddell \& Seviour, 1998; Soddell et al., 1998), a proposition underpinned by the results of the present investigation.

DNA from strains $\mathrm{J} 81^{\mathrm{T}}$ and $\mathrm{J} 82$ was extracted with a MoBio Laboratories UltraClean Soil DNA kit (Geneworks). 16S rRNA genes were PCR-amplified with universal primers $27 \mathrm{f}$ and 1525 r, amplicons were purified with a QIA Quick PCR purification kit (Qiagen) and cloning was completed using pGEM-T Easy vector system II (Promega). The resultant preparations were fully sequenced with primers M13F, 
M13R, 530F and 907R with Applied Biosystems PRISM BigDye 3.1 Terminator chemistry and then sequenced at the DNA Micromon Sequencing Facility of Monash University (Clayton, Australia). The 16S rRNA gene sequence results were compared with corresponding data retrieved from the Ribosomal Database Project (http://rdp.cme.msu.edu/) for representatives of the genera classified in the suborder Corynebacterineae. Phylogenetic trees were inferred using the maximum-likelihood (Felsenstein, 1981), maximumparsimony (Kluge \& Farris, 1969) and neighbour-joining (Saitou \& Nei, 1987) tree-making algorithms. An evolutionary distance matrix was generated for the neighbour-joining algorithm using the distance model of Jukes \& Cantor (1969). The unrooted tree topologies were subjected to bootstrap analysis (Felsenstein, 1985) of the neighbourjoining dataset, using the SEQBOOT and CONSENSE options from the PHYLIP package (Felsenstein, 1989).

Almost-complete 16S rRNA gene sequences (1519 nt) corresponding to Escherichia coli positions 27-1525 were obtained for the two strains. It is evident from Fig. 1 that the organisms have identical 16S rRNA gene sequences and form a deep-rooted lineage in the Corynebacterineae tree that can be equated with branches corresponding to recognized genera, a result consistent with their recognition as members of a novel genus. The strains tested are most closely related to members of Gordonia species with validly published names (93.7-95.7\% similarity) and to the type strain of S. piniformis ( $95 \cdot 5 \%$ similarity).
Chemotaxonomic studies were carried out to determine whether $\mathrm{J} 81^{\mathrm{T}}$ merited generic status within the suborder Corynebacterineae. Standard procedures were used for the extraction and analysis of fatty acids (MIDI system; http:// www.midi-inc.com/), isoprenoid quinones (Minnikin et al., 1984), muramic acid (Uchida et al., 1999), mycolic acids (Minnikin et al., 1980), polar lipids (Minnikin et al., 1984) and sugars (Schaal, 1985). The chain lengths of the mycolic acids were determined according to the method described by Linos et al. (1999). The isolate contained the following: meso-diaminopimelic acid, arabinose and galactose (wall chemotype IV sensu Lechevalier \& Lechevalier, 1970); $N$ glycolated muramic acid; a dihydrogenated menaquinone with eight isoprene units $\left[\mathrm{MK}-8\left(\mathrm{H}_{2}\right)\right]$ as the predominant menaquinone; mycolic acids within the range $\mathrm{C}_{44}-\mathrm{C}_{52}$; and diphosphatidylglycerol, phosphatidylethanolamine, phosphatidylglycerol, phosphatidylinositol and phosphatidylinositol mannosides as major polar lipids (phospholipid type 2; Lechevalier et al., 1977). This chemical profile serves to distinguish the tested strain from members of all of the genera that encompass mycolic-acid-containing organisms (Table 1), apart from representatives of the genus Rhodococcus that have mycolic acids towards the upper carbon range (Goodfellow et al., 1998a).

Strain $\mathrm{J} 81^{\mathrm{T}}$ was also characterized by the presence of large proportions of the fatty acids oleic acid $\left(\mathrm{C}_{18: 1} ; 46 \cdot 5 \%\right.$ of the total), palmitic acid $\left(\mathrm{C}_{16: 0} ; 26 \cdot 3 \%\right)$ and palmitoleic acid $\left(\mathrm{C}_{16: 1} ; 16 \cdot 8 \%\right)$ and relatively small proportions of myristic

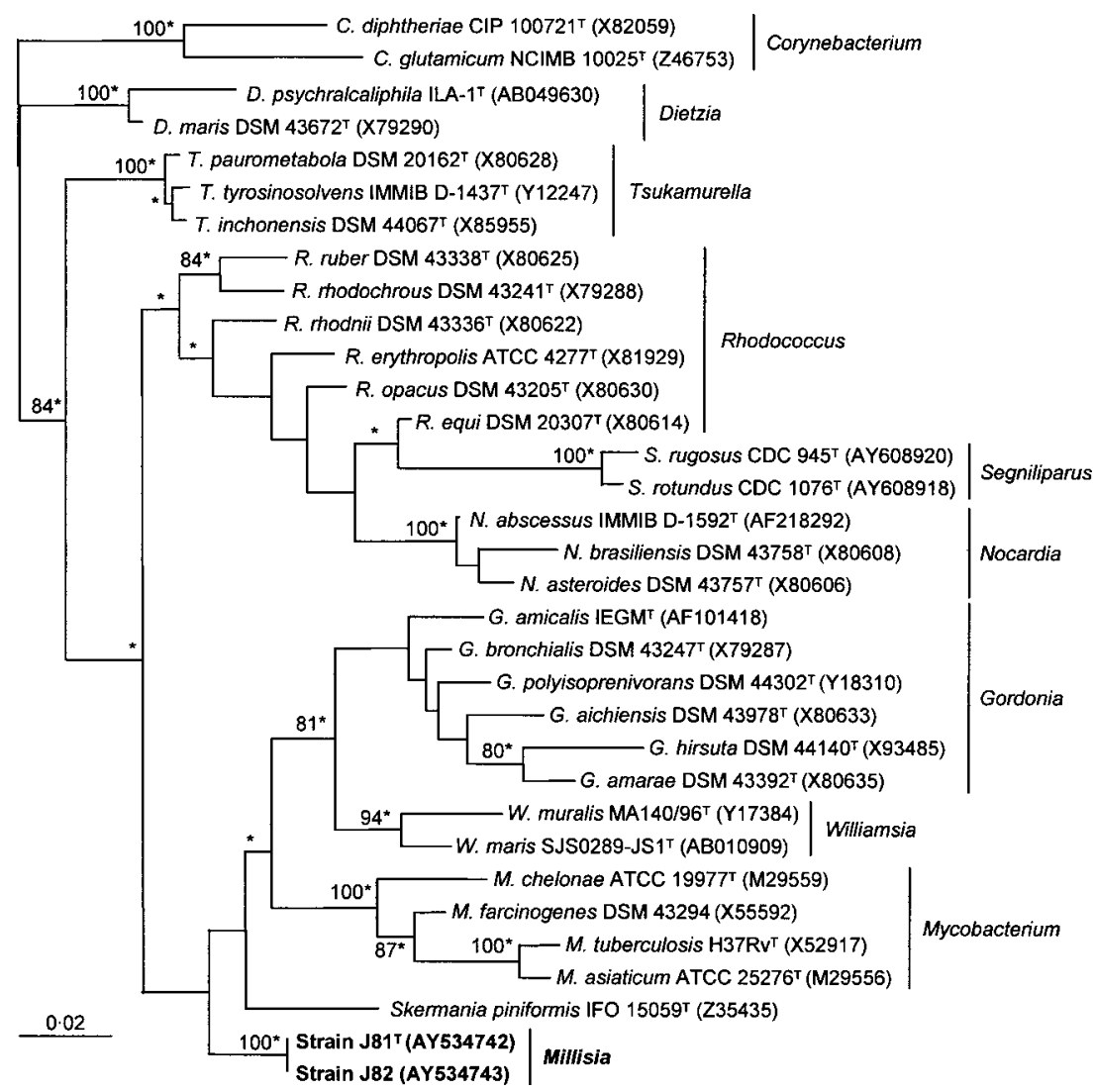

Fig. 1. Neighbour-joining tree (Saitou \& Nei, 1987), based on almost-complete 16S rRNA gene sequences, showing relationships between strains $\mathrm{J} 81^{\top}$ and $\mathrm{J} 82$ and representatives of genera classified in the suborder Corynebacterineae. Asterisks indicate branches of the tree that were also found using the maximum-likelihood (Felsenstein, 1981) and maximum-parsimony (Kluge \& Farris, 1969) tree-making algorithms. Numbers at nodes indicate levels of bootstrap support (\%) based on a neighbour-joining analysis of 1000 resampled datasets; only values above $75 \%$ are shown. Bar, 0.02 substitutions per nucleotide position. 
Table 1. Chemical and morphological properties of strain $J 81^{\top}$ and representatives of genera that contain mycolic-acidcontaining organisms

Data for established genera are from Soddell \& Seviour (1994), Butler et al. (2005) and Goodfellow \& Maldonado (2006). PE indicates the presence $(+)$ or absence $(-)$ of phosphatidylethanolamine. ND, No data.

\begin{tabular}{|c|c|c|c|c|c|c|}
\hline Strain/genus & $\begin{array}{l}\text { Major } \\
\text { menaquinone }\end{array}$ & $\begin{array}{l}\text { Muramic acid } \\
\text { acyl type }\end{array}$ & $\begin{array}{l}\text { Mycolic acids } \\
\text { (no. of carbons) }\end{array}$ & PE & $\begin{array}{c}\text { DNA G + C } \\
\text { content }(\mathrm{mol} \%)\end{array}$ & Cellular micromorphology \\
\hline Strain $\mathrm{J} 81^{\mathrm{T}}$ & $\mathrm{MK}-8\left(\mathrm{H}_{2}\right)$ & Glycolated & $44-52$ & + & $64 \cdot 7$ & $\begin{array}{l}\text { Characteristic rudimentary right-angled } \\
\text { branching }\end{array}$ \\
\hline Dietzia & $\mathrm{MK}-8\left(\mathrm{H}_{2}\right)$ & Acetylated & $34-39$ & + & $66-73$ & Short rods and cocci \\
\hline Corynebacterium & $\mathrm{MK}-8\left(\mathrm{H}_{2}\right)$ & Acetylated & $22-38$ & - & $51-67$ & Pleomorphic rods \\
\hline Gordonia & MK- $9\left(\mathrm{H}_{2}\right)$ & Glycolated & $46-66$ & + & $63-69$ & $\begin{array}{l}\text { Rods and cocci/moderately branched } \\
\text { hyphae }\end{array}$ \\
\hline Mycobacterium & MK-9 $\left(\mathrm{H}_{2}\right)$ & Glycolated & $60-90$ & + & $62-70$ & Rods, occasionally branched filaments \\
\hline Nocardia & MK-8 $\left(\mathrm{H}_{4}\right.$, co-cycl. $)$ & Glycolated & $40-64$ & + & $64-72$ & $\begin{array}{l}\text { Mycelium that fragments into rods and } \\
\text { cocci }\end{array}$ \\
\hline Rhodococcus & $\mathrm{MK}-8\left(\mathrm{H}_{2}\right)$ & Glycolated & $30-54$ & + & $67-73$ & $\begin{array}{l}\text { Rods to extensively branched elements } \\
\text { that fragment }\end{array}$ \\
\hline Segniliparus & ND & ND & ND & ND & $68-72$ & Rods \\
\hline
\end{tabular}

acid $(1 \cdot 8 \%)$, stearic acid $(2 \cdot 3 \%)$ and tuberculostearic acid $(3.0 \%)$. The large proportion of oleic acid and the low proportion of tuberculostearic acid distinguish the organism from representatives of all of the genera composed of mycolic-acid-containing actinomycetes (Kämpfer et al., 1999; Yoon et al., 2000; Gürtler et al., 2001; Kattar et al., 2001; Kim et al., 2002; Linos et al., 2002; Nam et al., 2003; Butler et al., 2005). The highest identification score in the MIDI system $(0 \cdot 041)$ for the tested strain was with representatives of the genera Dietzia and Rhodococcus, but this score is too low to allow assignment of the strain to either of these genera; consequently, strain $\mathrm{J} 81^{\mathrm{T}}$ cannot be assigned to any of the taxa present in the MIDI database. Onedimensional TLC showed that the organism contained mycolic acids with an $R_{\mathrm{f}}$ value similar to those found for the Gordonia and Rhodococcus marker strains $\left(R_{\mathrm{f}} 0 \cdot 37-0 \cdot 38\right)$. Strain $\mathrm{J} 81^{\mathrm{T}}$ was also compared with representatives of mycolic-acid-containing genera by using a Curie-point pyrolysis mass spectrometric procedure described by Goodfellow et al. (1998b). It is apparent from Fig. 2 that the organism is well separated from the other strains, as it occupies a distinct area in the resultant taxospace.

The DNA G+C content was determined for strain $\mathrm{J}^{\mathrm{T}} \mathrm{T}^{\mathrm{T}}$. Isolation and purification of the DNA was achieved by following the procedure described by Pitcher et al. (1989). The $\mathrm{G}+\mathrm{C}$ content of the DNA preparation was determined using the reverse-phase HPLC method described by Tamaoka (1994). The molar G+C content, calculated using the method described by Mesbah et al. (1989), was $64 \cdot 7 \mathrm{~mol} \%$.

It is apparent from the excellent congruence found between the present chemotaxonomic and earlier numerical phenetic data (Soddell et al., 1998) that strain $\mathrm{J} 81^{\mathrm{T}}$ should be classified in a novel genus within the suborder Corynebacterineae. This conclusion is strongly supported by the $16 \mathrm{~S}$ rRNA sequence data, which show that strains $\mathrm{J} 81^{\mathrm{T}}$ and $\mathrm{J} 82$ form a distinct

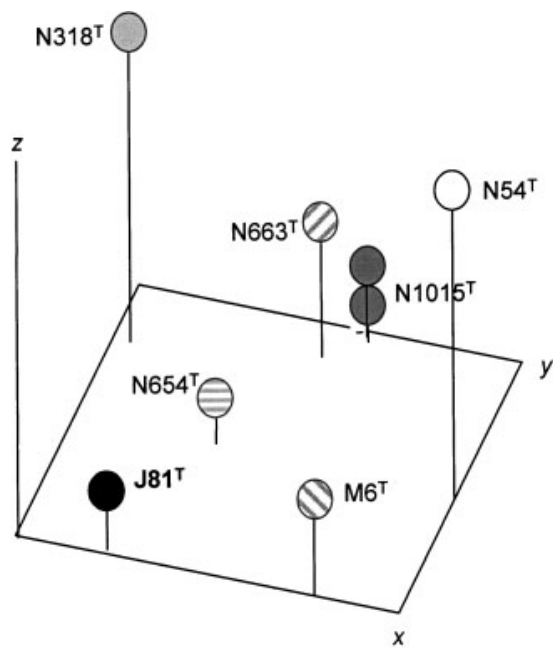

Fig. 2. Three-dimensional ordination diagram based on Curiepoint pyrolysis mass spectral data showing relationships between strain $\mathrm{J} 81^{\top}$ and strains representing genera classified in the suborder Corynebacterineae. The plot is based on the first three canonical variates of a principal component-canonical variate analysis. The first three axes account for $77 \cdot 3,16 \cdot 1$ and $3.5 \%$ of the total variation between the strains. $\mathrm{N} 1015^{\top}$, duplicated cultures of Dietzia maris; $\mathrm{N} 54^{\top}$, Gordonia bronchialis; $\mathrm{M6}^{\top}$, Mycobacterium peregrinum; N318 ${ }^{\top}$, Nocardia brasiliensis; $\mathrm{N}^{\mathrm{T}}{ }^{\mathrm{T}}$, Rhodococcus rhodochrous; $\mathrm{N}_{663}{ }^{\top}$, Tsukamurella paurometabola. 
lineage in the Corynebacterineae gene tree, and by the distinctive cellular morphology of these organisms (Soddell \& Seviour, 1994). It is proposed that these strains be classified in a novel monospecific genus. The name proposed for this taxon is Millisia brevis gen. nov., sp. nov.

Members of mycolic-acid-containing genera have been assigned to six suprageneric taxa, the families Corynebacteriaceae, Dietziaceae, Gordoniaceae, Mycobacteriaceae, Nocardiaceae and Tsukamurellaceae, mainly on the basis of $16 \mathrm{~S}$ rRNA signature nucleotides (Stackebrandt et al., 1997; Goodfellow \& Maldonado, 2006). The Millisia strains have signature nucleotides that are characteristic of the subclass Actinobacteridae and of the suborder Corynebacterineae, but not of those of their nearest phylogenetic neighbours in the family Gordoniaceae. Further comparative taxonomic studies on additional Millisia strains are needed to determine whether this taxon should be assigned to a novel family. An organism associated with a deep-water marine invertebrate has been found to share an identical partial $16 \mathrm{~S}$ rRNA gene sequence with M. brevis $\mathrm{J} 81^{\mathrm{T}}$ (Sfanos et al., 2005).

\section{Description of Millisia gen. nov.}

Millisia (Mil.li'si.a. N.L. fem. n. Millisia named after Professor Emeritus Nancy F. Millis AC, MBE, a celebrated Australian microbiologist who promoted wastewater microbiology in Australia).

The description is based on data taken from this and previous studies (Soddell \& Seviour, 1998; Soddell et al., 1998). Aerobic, Gram-positive to Gram-variable, acid-alcoholfast, non-motile, catalase-positive actinomycetes that form non-spore-forming rods showing rudimentary right-angled branching and which contain polyphosphate storage granules. Form salmon-pink, irregular colonies with filamentous margins and sparse, unbranched aerial hyphae on glucose/yeast extract agar. Colonies are matt and dry in appearance, soft in texture and easy to emulsify. Diffusible pigments are not formed. Whole-organism hydrolysates are rich in meso-diaminopimelic acid, arabinose and galactose. Contain $\mathrm{N}$-glycolated muramic acid residues. The predominant menaquinone has eight isoprene units, one of which is hydrogenated. Diphosphatidylglycerol, phosphatidylethanolamine, phosphatidylglycerol, phosphatidylinositol and phosphatidylinositol mannosides are the major polar lipids. The mycolic acids present have $44-52$ carbons (principal components $\mathrm{C}_{48}, \mathrm{C}_{50}$ and $\mathrm{C}_{52}$ ). Oleic, palmitic and palmitoleic acids are the predominant fatty acids, and there are relatively small proportions of myristic, stearic and tuberculostearic acids. The $\mathrm{G}+\mathrm{C}$ content of the genomic DNA of the type strain of the type species is $64 \cdot 7 \mathrm{~mol} \%$. The genus forms a distinct lineage in the Corynebacterineae $16 \mathrm{~S}$ rRNA gene tree. The type species is Millisia brevis.

\section{Description of Millisia brevis sp. nov.}

Millisia brevis (bre'vis. L. fem. adj. brevis short, denoting the formation of short, branched rods).
The description is based upon data taken from Soddell et al. (1998). In addition to having the properties given in the genus description, the organism degrades Tweens 20, 40 and 60, but not adenine, casein, elastin, hypoxanthine, tyrosine or xanthine. Hydrolyses allantoin (weakly) and urea (strongly) but does not reduce nitrate or produce $m$ - or p-nitrophenol oxidases. Grows between 15 and $35^{\circ} \mathrm{C}$, but not at 10 or $37^{\circ} \mathrm{C}$, and at $\mathrm{pH} 5 \cdot 5-9 \cdot 5$. Cellobiose, ethanol, fructose, glucose, glycerol, myo-inositol, mannitol, mannose, sucrose and trehalose are used as sole sources of carbon for energy and growth, but arabinose, galactose, inulin, lactose, maltose, melezitose, raffinose, rhamnose, salicin, sorbitol and xylose (all at $0 \cdot 1 \%$, w/v) are not. Similarly, $m$ hydroxybenzoic acid, sebacic acid, sodium butyrate, sodium gluconate, sodium lactate, sodium octanoate and sodium pyruvate are used as sole carbon sources, but acetamide, benzamide, $p$-hydroxybenzoic acid, pimelic acid, sodium benzoate, sodium succinate, sodium tartrate, testosterone and tyrosine $(0.01 \%, \mathrm{w} / \mathrm{v})$ are not; variable results are obtained with $p$-cresol, sodium acetate, sodium adipate, sodium citrate, sodium fumarate, sodium malate and sodium propionate (all at $0.01 \%, \mathrm{w} / \mathrm{v}$ ). Coconut oil, glycerol trioleate, kerosene, hexadexane, olive oil, paraffin oil, safflower oil and xylene (weakly) are used as sole carbon sources in shake-flask liquid culture (all at $1 \%$, v/v). Variable results are obtained with acetamide and serine as sole carbon and nitrogen sources, but trimethyldiamine does not support growth. Grows in the presence of crystal violet $(0 \cdot 0001 \%, \mathrm{w} / \mathrm{v})$, phenol $(0 \cdot 01 \%, \mathrm{w} / \mathrm{v})$ and phenyl ethanol $(0.02$ and $0.03 \%, \mathrm{v} / \mathrm{v})$, but is sensitive to crystal violet $(0.001 \%, \mathrm{w} / \mathrm{v})$, phenol $(0 \cdot 1 \%, \mathrm{w} / \mathrm{v})$, sodium azide $(0.01$ and $0.02 \%, \mathrm{w} / \mathrm{v})$, sodium chloride $(5$ and $7 \%, \mathrm{w} / \mathrm{v})$ and penicillin G (10 IU). Produces acid phosphatase, alkaline phosphatase (weakly), esterase $\left(\mathrm{C}_{4}\right)$, esterase lipase $\left(\mathrm{C}_{8}\right), \alpha$-glucosidase, $\beta$-glucosidase, leucine arylamidase, $\alpha$-mannosidase (weakly), naphthol-AS-BI-phosphohydrolase and valine arylamidase, but not chymotrypsin, lipase $\left(\mathrm{C}_{14}\right)$, $\alpha$-fucosidase, $\alpha$-galactosidase, $\beta$-galactosidases, $\beta$-glucuronidase, $N$-acetyl- $\beta$-glucosaminidase or trypsin; variable results are obtained for cystine arylamidase.

The type strain, strain $\mathrm{J} 81^{\mathrm{T}}\left(=\mathrm{DSM} 44463^{\mathrm{T}}=\mathrm{NRRL}\right.$ B-24424 $4^{\mathrm{T}}$ ), was isolated from activated sludge foam from Tamworth Sewage Treatment Plant, New South Wales, Australia.

\section{References}

Butler, W. R., Floyd, M. M., Brown, J., Toney, S. R., Daneshvar, M., Cooksey, R. S., Carr, J., Steigerwalt, A. \& Charles, N. (2005). Novel mycolic acid-containing bacteria in the family Segniliparaceae fam. nov., including the genus Segniliparus gen. nov., with descriptions of Segniliparus rotundus sp. nov. and Segniliparus rugosus sp. nov. Int J Syst Evol Microbiol 55, 1615-1624.

Chun, J., Blackall, L. L., Kang, S.-O., Hah, Y.-C. \& Goodfellow, M. (1997). A proposal to reclassify Nocardia pinensis Blackall et al. as Skermania piniformis gen. nov., comb. nov. Int J Syst Bacteriol 47, 127-131.

Felsenstein, J. (1981). Evolutionary trees from DNA sequences: a maximum likelihood approach. J Mol Evol 17, 368-376. 
Felsenstein, J. (1985). Confidence limits on phylogenies: an approach using the bootstrap. Evolution 39, 783-791.

Felsenstein, J. (1989). PHYLIP - phylogeny inference package (version 3.2). Cladistics 5, 164-166.

Goodfellow, M. \& Maldonado, L. A. (2006). The families Dietziaceae, Gordoniaceae, Nocardiaceae and Tsukamurellaceae. In The Prokaryotes. A Handbook on the Biology of Bacteria, 3rd edn, vol. 3, Archaea and Bacteria: Firmicutes, Actinomycetes. Edited by M. Dworkin, S. Falkow, E. Rosenberg, K. H. Schleifer \& E. Stackebrandt. New York: Springer (in press).

Goodfellow, M., Alderson, M. \& Chun, J. (1998a). Rhodococcal systematics: problems and developments. Antonie van Leeuwenhoek 74, 3-20.

Goodfellow, M., Stainsby, F. M., Davenport, R., Chun, J. \& Curtis, T. (1998b). Activated sludge foaming: the true extent of actinomycete diversity. Water Sci Technol 37 (4-5), 511-519.

Goodfellow, M., Isik, K. \& Yates, E. (1999). Actinomycete systematics: an unfinished synthesis. Nova Acta Leopold NF80 (312), 47-82.

Gürtler, V., Smith, R., Mayall, B., Pötter-Reinemann, G., Stackebrandt, E. \& Kroppenstedt, R. M. (2001). Nocardia veterana sp. nov., isolated from human bronchial lavage. Int $J$ Syst Evol Microbiol 51, 933-936.

Gürtler, V., Mayall, B. C. \& Seviour, R. (2004). Can whole organism genome analysis refine the taxonomy of the genus Rhodococcus? FEMS Microbiol Rev 28, 377-403.

Jukes, T. H. \& Cantor, C. R. (1969). Evolution of protein molecules. In Mammalian Protein Metabolism, vol. 3, pp. 21-132. Edited by H. N. Munro. New York: Academic Press.

Kämpfer, P., Andersson, M. A., Rainey, F. A., Kroppenstedt, R. M. \& Salkinoja-Salonen, M. (1999). Williamsia muralis gen. nov., sp. nov., isolated from the indoor environment of a children's day care centre. Int J Syst Bacteriol 49, 681-687.

Kattar, M. M., Cookson, B. T., Carlson, L. C. \& 7 other authors (2001). Tsukamurella strandjordae sp. nov., a proposed new species causing sepsis. J Clin Microbiol 39, 1467-1476.

Kim, K. K., Roth, A., Andrees, S., Lee, S. T. \& Kroppenstedt, R. M. (2002). Nocardia pseudovaccinii sp. nov. Int J Syst Evol Microbiol 52, $1825-1829$.

Klatte, S., Rainey, F. A. \& Kroppenstedt, R. M. (1994). Transfer of Rhodococcus aichiensis Tsukamura 1982 and Nocardia amarae Lechevalier and Lechevalier 1994 to the genus Gordonia as Gordonia aichiensis comb. nov. and Gordonia amarae comb. nov. Int J Syst Bacteriol 44, 769-773.

Kluge, A. G. \& Farris, F. S. (1969). Quantitative phyletics and the evolution of anurans. Syst Zool 18, 1-32.

Lechevalier, M. P. \& Lechevalier, H. A. (1970). Chemical composition as a criterion in the classification of aerobic actinomycetes. Int J Syst Bacteriol 20, 434-443.

Lechevalier, M. P. \& Lechevalier, H. A. (1974). Nocardia amarae sp. nov., an actinomycete common in foaming activated sludge. Int J Syst Bacteriol 24, 278-288.

Lechevalier, M. P., De Bièvre, C. \& Lechevalier, H. A. (1977). Chemotaxonomy of aerobic actinomycetes: phospholipid composition. Biochem Syst Evol 5, 249-260.

Lemmer, H. \& Kroppenstedt, R. M. (1984). Chemotaxonomy and physiology of some actinomycetes isolated from scumming activated sludge. Syst Appl Microbiol 5, 124-135.

Linos, A., Steinbüchel, A., Spröer, C. \& Kroppenstedt, R. M. (1999). Gordonia polyisoprenovorans sp. nov., a rubber-degrading actinomycete isolated from an automobile tyre. Int J Syst Bacteriol 49, 1785-1791.
Linos, A., Berekaa, M. M., Steinbüchel, A., Kim, K. K., Spröer, C. \& Kroppenstedt, R. M. (2002). Gordonia westfalica sp. nov., a novel rubber-degrading actinomycete. Int J Syst Evol Microbiol 52, 1133-1139.

Mesbah, M., Premachandran, U. \& Whitman, W. B. (1989). Precise measurement of the $\mathrm{G}+\mathrm{C}$ content of deoxyribonucleic acid by highperformance liquid-chromatography. Int J Syst Bacteriol 39, 159-167.

Minnikin, D. E., Hutchinson, I. G., Goodfellow, M. \& Caldicott, A. B. (1980). Thin-layer chromatography of methanolysates of mycolic acid-containing bacteria. J Chromatogr 188, 221-233.

Minnikin, D. E., O’Donnell, A. G., Goodfellow, M., Alderson, G., Athalye, M., Schaal, A. \& Parlett, J. K. (1984). An integrated procedure for the extraction of isoprenoid quinones and polar lipids. J Microbiol Methods 2, 233-241.

Nam, S.-W., Chun, J., Kim, S., Kim, W., Zakrzewska-Czerwinska, J. \& Goodfellow, M. (2003). Tsukamurella spumae sp. nov., a novel actinomycete associated with foaming in activated sludge plants. Syst Appl Microbiol 26, 367-375.

Nam, S.-W., Kim, W., Chun, J. \& Goodfellow, M. (2004). Tsukamurella pseudospumae sp. nov., a novel actinomycete isolated from activated sludge foam. Int J Syst Evol Microbiol 54, 1209-1212.

Pitcher, D. G., Saunders, N. A. \& Owen, R. J. (1989). Rapid extraction of bacterial genomic DNA with guanidium thiocyanate. Lett Appl Microbiol 8, 151-156.

Saitou, N. \& Nei, M. (1987). The neighbor-joining method: a new method for reconstructing phylogenetic trees. Mol Biol Evol 4, 406-425.

Schaal, K. P. (1985). Laboratory diagnosis of actinomycete diseases. In Chemical Methods in Bacterial Systematics, pp. 359-381. Edited by M. Goodfellow \& D. E. Minnikin. London: Academic Press.

Sfanos, K., Harmody, D., Dang, P., Ledger, A., Pomponi, S., McCarthy, P. \& Lopez, J. (2005). A molecular systematic survey of cultured microbial associates of deep-water marine invertebrates. Syst Appl Microbiol 28, 242-264.

Soddell, J. A. (1999). Foaming. In Microbiology of Activated Sludge, pp. 161-202. Edited by S. J. Seviour \& L. L. Blackall. Dordrecht: Kluwer.

Soddell, J. A. \& Seviour, R. J. (1990). Microbiology of foaming in activated sludge plants - a review. J Appl Bacteriol 69, 145-176.

Soddell, J. A. \& Seviour, R. J. (1994). Incidence and morphological variability of Nocardia pinensis in Australian activated sludge plants. Water Res 28, 2343-2351.

Soddell, J. A. \& Seviour, R. J. (1995). Relationship between temperature and growth of organisms causing Nocardia foams in activated sludge plants. Water Res 29, 1555-1558.

Soddell, J. A. \& Seviour, R. J. (1998). Numerical taxonomy of Skermania piniformis and related isolates from activated sludge. J Appl Microbiol 84, 272-284.

Soddell, J. A., Seviour, R. J., Blackall, L. L. \& Hugenholtz, P. (1998). New foam-forming nocardioforms found in activated sludge. Water Sci Technol 37 (4-5), 495-502.

Stackebrandt, E., Rainey, F. A. \& Ward-Rainey, N. L. (1997). Proposal for a new hierarchic classification system, Actinobacteria classis nov. Int J Syst Bacteriol 47, 479-491.

Stainsby, F. M., Soddell, J., Seviour, R., Upton, J. \& Goodfellow, M. (2002). Dispelling the "Nocardia amarae" myth: a phylogenetic and phenotypic study of mycolic acid-containing actinomycetes isolated from activated sludge foam. Water Sci Technol 46 (1-2), 81-90.

Tamaoka, J. (1994). Determination of DNA base composition. In Chemical Methods in Prokaryotic Systematics, pp. 463-470. Edited by M. Goodfellow \& A. G. O’Donnell. Chichester: Wiley. 
Uchida, K., Kudo, T., Suzuki, K. \& Nakase, T. (1999). A new rapid method of glycolate test by diethyl ether extraction which is applicable to a small amount of bacterial cells of less than one milligram. J Gen Appl Microbiol 45, 49-56.
Yoon, J.-H., Cho, Y.-G., Kang, S.-S., Kim, S. B., Lee, S. T. \& Park, Y.-H. (2000). Rhodococcus koreensis sp. nov., a 2,4dinitrophenol-degrading bacterium. Int J Syst Evol Microbiol 50, 1193-1201. 